\title{
Differential Susceptibility of Prunus Germplasm (Subgenus Amygdalus) to a California Isolate of Xylella fastidiosa
}

\author{
Craig A. Ledbetter ${ }^{1}$ and Elizabeth E. Rogers
}

U.S. Department of Agriculture, Agricultural Research Service, San Joaquin Valley Agricultural Sciences Center, Crop Diseases, Pests and Genetics Research Unit, 9611 S. Riverbend Avenue, Parlier, CA 93648-9757

Additional index words. almond, hybrid, peach, rootstock, titer

\begin{abstract}
Seedling peach (Prunus persica Batsch) and clonal peach-almond hybrids are popular rootstock choices for commercial almond growers in California. In this study, clonal replicates of peach and almond $[P$. dulcis (Mill.) D.A. Webb] rootstock germplasm and a first-generation peach-almond hybrid created from them were challenged with Xylella fastidiosa isolate M23. Clonal replicates were needle-inoculated with M23 and maintained in a greenhouse environment for a growing season. Typical almond leaf scorch disease symptoms began to develop on M23-inoculated almonds 11 weeks after inoculation. No leaf scorch symptoms were observed on M23-inoculated peach or peachalmond hybrids. Quantitative real-time polymerase chain reaction revealed consistent levels of $X$. fastidios $a$ DNA among inoculated almond replicates, whereas $X$. fastidiosa DNA was undetectable in replicates of peach-almond hybrids. A trace level of $X$. fastidiosa DNA was detected in a single peach replicate, and statistical analysis demonstrated that this level differed significantly $(P<\mathbf{0 . 0 0 1})$ from that detected in almond replicates. Selected almonds were further sampled sequentially along their meristematic axes to examine bacterial titer throughout the trees. Selected almond trees differed significantly $(P=0.036)$ in bacterial titer, but no significant differences were noted in levels of $X$. fastidiosa from different vertical sections of the main growth axes. The results suggest that peach and peach-almond hybrid rootstock germplasm used by commercial almond tree nurseries in California are not primary inoculum sources for $X$. fastidiosa-induced diseases.
\end{abstract}

Among the cultivated hardy trees and shrubs of North America, five subgenera are defined for Prunus by Rehder (1940), among which are the species of Amygdalus. This subgenus includes peach ( $P$. persica), a widely grown tree fruit throughout North America, and almond ( $P$. dulcis), a tree nut cultivated almost exclusively in California orchards in North America. Both species are economically important for California and have significant acreage throughout its various growing regions. In 2007, almonds were a $\$ 2$ billion U.S. crop grown on nearly 250,000 ha, whereas peaches (fresh market freestones and canning clings) occupied $\approx 25,000$ ha in California (Anon., 2008).

Xylella fastidiosa $(X f)$ is a genetically diverse Gram-negative bacterium with numerous hosts (Freitag, 1951), including a number of Prunus species, typically causing irregular patterns of leaf necrosis or "scorching" in infected plants (Hopkins and Purcell, 2002).

Received for publication 28 July 2009. Accepted for publication 3 Sept. 2009.

We thank Dr. Jianchi Chen for supplying the primer sequences. We gratefully acknowledge the technical assistance of Mark Schreiber and Sherry Peterson in the laboratory and greenhouse, respectively. Thanks are also given to Dr. Drake Stenger for helpful comments in the editorial review of the manuscript.

${ }^{1}$ To whom reprint requests should be addressed; e-mail Craig.Ledbetter@ars.usda.gov.
In California, $X f$ is responsible for both Pierce's disease (PD) of grapes and almond leaf scorch disease (ALSD) in almond. $X f$ biotype differences based on single nucleotide polymorphisms of $16 \mathrm{~S}$ rDNA sequences have been determined (Chen et al., 2005) with "A-genotype" biotypes causing only ALSD and "G-genotype" biotypes capable of causing both PD and ALSD. Using rootgraft transmission studies and serology, Wells et al. (1981) demonstrated biotype differences for $X f$ causing both phony peach disease and plum leaf scald in the southeastern United States. Healthy plums grafted with infected root segments from peach trees expressing phony peach symptoms developed leaf scald symptoms after 9 months of growth. However, similarly, healthy peach trees grafted with roots from plum trees expressing plum leaf scald remained symptomless even after 2 years of growth (Wells et al., 1983). Similar results have been noted for $X f$ biotypes responsible for citrus variegated chlorosis and coffee leaf scorch diseases (de Lima et al., 1998; Li et al., 2001). Several other transmission and molecularbased studies have demonstrated the complexity of $X f$ biotype-host interactions with regard to pathogenicity and fulfillment of Koch's postulates (Hernandez-Martinez et al., 2006; Mircetich et al., 1976; MonteroAstúa et al., 2007; Raju et al., 1982).

Both random and aggregated patterns of ALSD distribution were observed in sampled almond orchards (Groves et al., 2005), indicating differences in almond cultivar susceptibility to the $X f$ biotypes present and raising questions relative to the original source(s) of primary inoculum. Using geostatistics to determine spatial patterns of disease development, Roberto et al. (2002) concluded that commercial citrus nurseries were the primary sources of citrus variegated chlorosis-infected orange trees in citrus orchards; however, primary inoculum sources of ALSD in almond orchards are as yet undetermined. Natural vegetation in habitats bordering California commercial grape and stone fruit orchards has been shown to harbor $X f$ and has been implicated as primary inoculum sources for PD in adjacent vineyards (Redak et al., 2004). When these same habitats border commercial tree nurseries, $X f$-infected vectors are capable of inoculating susceptible rootstocks and budded trees throughout the growing season.

Susceptibility of almond to $X f$ biotypes causing PD and ALSD is well documented. Although accessions of peach are susceptible to phony peach $X f$ biotypes, several studies indicate that they resist infection from $X f$ biotypes responsible for PD and ALSD (Mircetich et al., 1976; Wells et al., 1983). Seed-propagated peaches are used extensively in California as rootstocks for almonds and other stone fruit species with rootstock cultivars such as 'Nemaguard' being favored by growers because of resistance to root knot nematodes (Meloidogyne incognita and $M$. javanica). In cases in which more scion vigor is desirable, peach $\times$ almond (PEAL) hybrids are being used, predominantly in newer almond plantings. The susceptibility of PEAL hybrids to $X f$ isolates causing ALSD is currently unknown. In this study, we examined disease development and bacterial titer within parental peach and almond genotypes together with an interspecific hybrid created from them over the course of a growing season.

\section{Materials and Methods}

Plant materials. On-site trees of peach (P248-139), almond (Y113-20-99), and PEAL hybrid (062002) derived from them were used as clonal sources in the study. The trees are part of the Prunus breeding effort at the San Joaquin Valley Agricultural Sciences Center in Parlier, CA. P248-139 is an $F_{1}$ hybrid of 'Harrow Blood' $\times$ 'Okinawa' parentage created for the generation of vegetative diversity in the development of Prunus rootstocks. Accession Y113-20-99 ('Tuono' $\times$ 74-26) has been selected as a self-compatible hard-shell almond, but also demonstrates good performance as an almond seedling rootstock, having good field emergence rates under climactic conditions in the central San Joaquin Valley. PEAL hybrid 062002 was created as a prospective vigorous clonal rootstock selection for almond trees, and we therefore desired to examine its reaction to an aggressive $X f$ isolate endemic to central California. Clonal materials of these three 
accessions were dormant-grafted on 1-yearold 'Nemaguard' peach seedling rootstocks.

One-year-old 'Nemaguard' peach seedlings (Reisner Nursery, Visalia, CA) were used as rootstocks for the dormant scions. The dormant rootstocks were planted in 15.6L pots filled with \# 4 Sunshine Mix (SunGro, Seba Beach, Alberta, Canada) providing sufficient volume for root development during the growing period. Three weeks after planting, rootstocks were whip-grafted during mid-Feb. 2008 and allowed to develop and break bud under ambient environmental conditions. Trees demonstrating vegetative bud swell on the grafted scion were then moved to a climate-controlled greenhouse in mid-March. Trees were maintained in a greenhouse throughout the growing season, and cultural practices, including irrigation, fertilization, and insecticides, were administered as needed to maintain an optimal environment for plant growth. Vegetative buds pushed quickly in response to the warmer greenhouse environment, and growing trees were trained to a single vegetative shoot.

Xf inoculations. Xylella fastidiosa isolate 'M23', previously isolated from ALSDaffected almond trees in Kern County, CA, was used for all tree inoculations. Isolate M23 is a G-genotype and pathogenic to both almond and grape (Chen et al., 2005). Bacteria were grown in PW medium as described by Davis et al. (1981). Log-phase bacterial cells were harvested after 10 to $14 \mathrm{~d}$ of growth following previously described procedures (Chen et al., 2008). Scion inoculations were accomplished by needle penetrations of stems of $\approx 4$ to $6 \mathrm{~mm}$ diameter at the basal portion $(5 \mathrm{~cm}$ to $10 \mathrm{~cm})$ of current-season growth. Approximately $10 \mu \mathrm{L}$ of inoculum was used for each inoculation; two inoculations were performed on each tree at each of two locations spaced 1 to $2 \mathrm{~cm}$ apart. Six trees of both peach and almond were $X f$-inoculated, whereas there were seven PEAL trees inoculated with $X f$. Three control trees of each group were similarly inoculated with sterile distilled water. Immediately after inoculation, scions were pruned to a uniform height $10 \mathrm{~cm}$ to $15 \mathrm{~cm}$ above the inoculation site.

Plant sampling to detect Xf. All plants were initially sampled 20 weeks postinoculation to determine the presence of $X f$ DNA. Petioles from two basal leaves near the inoculation site were harvested and lyophilized before analysis. A single DNA extraction from the petioles was used for three polymerase chain reactions (PCRs) per tree. Data reported from the initial harvest represent the mean \pm SD of the three PCR replicates.

Trees with quantifiable amounts of $X f$ DNA were further sampled at 21 weeks postinoculation. In these analyses, three separate DNA extractions were performed on pairs of petioles from basal leaves near the inoculation site. PCR was performed in triplicate on each DNA extraction. The triplicate PCRs were then averaged to provide a single titer value for each DNA extraction. These samples were used to determine differences in $X f$ titer between and within germplasm types.
At 24 weeks postinoculation, three $X f$ inoculated almond trees were used to examine differences in $X f$ titer along the main meristematic axes of the trees as well as between trees. Each examined tree was sampled sequentially in four vertical sections along the main axis, basal (inoculation site) or lowest section, through the upper (meristematic) section. Petiole pairs were again sampled from each section of the three trees chosen for analysis. A single DNA extraction was prepared from each petiole pair, and triplicate PCRs were performed.

$\mathrm{Xf}$ quantification. $\mathrm{Xf}$ titer in petioles was measured by quantitative real-time PCR. Total DNA was extracted from petioles by an adaptation of a previously reported method (Dellaporta et al., 1983) and further purified using nucleotide removal columns according to the manufacturer's instructions (Qiagen, Inc., Valencia, CA). PCR was performed on a Step One Plus real-time thermocycler using Applied Biosystem's Sybr Green Master Mix according to the manufacturer's instructions (Applied Biosystems, Foster City, CA). Primers Xf145-60F (5'-TACATCGGAATCTAC CTTATCGTG- $\left.3^{\prime}\right)$ and Xf145-60R (5'-ATG CGGTATTAGCGTAAGTTTC-3') that amplify portions of the $16 \mathrm{~S}$ ribosomal RNA gene were used for PCR. Total DNA was quantitated by $\mathrm{OD}_{260}$ on a NanoDrop- 1000 spectrophotometer (ThermoScientific, Wilmington, DE).

Statistical analyses. Data were compiled and analyzed in JMP stats (Version 7; SAS, Cary, NC) using the "Basic" category to obtain means and SDs of initial real-time PCR analyses. A $t$ test was used, assuming unequal variances, to compare $X f$ titer differences between peach and almond replicates. Analysis of variance (ANOVA) was used to examine effects of tree replicates and tree vertical sections on $X f$ titer. Before ANOVA, data were subjected to tests to ensure homogeneity of variance. If significant $F$-test statistics were obtained, Tukey's honestly significant difference test was used to compare differences among means.

\section{Results}

$X f$-inoculated and control trees grew vigorously in the greenhouse for the first several months without manifesting symptoms. In mid-July, $\approx 11$ weeks after inoculation, irregular patches of chlorosis/yellowing began to appear in leaves of inoculated almond trees. Discolored leaves first appeared just below the level where trees were initially pruned after inoculation. The discoloration intensified, leading to eventual necrotic patches (scorching) near leaf margins. At the same time, symptoms progressed acropetally in the newer leaves along the main growing axis. By mid-September, scorched leaves were evident from the inoculation site to within $30 \mathrm{~cm}$ of the shoot apex. Noninoculated almond trees and all trees of peach and PEAL remained symptomless throughout the growing season.

Initial PCR analyses of leaf petioles harvested near inoculation sites corresponded well with symptom development in $X f$-inoculated trees. Aside from a trace amount observed in one peach tree, $X f$ DNA was quantified only in $X f$-inoculated almond trees (Fig. 1). No $X f$ DNA was detected in any of the $X f$-inoculated PEAL trees. In these preliminary samples, levels of $X f$ DNA in the almond trees ranged from $2.17 \times 10^{-2} \pm 7.86 \times 10^{-4}$ to $1.32 \times 10^{-1}$ $\pm 3.21 \times 10^{-3} \mathrm{ng} X f \mathrm{DNA} / \mathrm{ng}$ total DNA and averaged $6.30 \times 10^{-2} \pm 1.49 \times 10^{-3} \mathrm{ng} X f \mathrm{DNA} /$ ng total DNA. In contrast, the trace level observed in one of six $X f$-inoculated peach trees was $1.80 \times 10^{-4} \pm 1.56 \times 10^{-5} \mathrm{ng} X f \mathrm{DNA} /$ ng total DNA, more than two orders of magnitude less than levels observed in almonds.

Additional samples were collected from trees testing positive for $X f$ DNA to determine whether significant differences in $X f$ titer existed between $X f$-infected peach and almond trees. In a comparison of $X f$ titer in petioles collected near inoculation sites, an unequal-variance $t$ test $(\mathrm{F}$ ratio $=49.104, \mathrm{df}=$ $1,17, \mathrm{t}$ ratio $=7.007$ ) revealed highly significant $(P<0.001)$ differences in titer of $X f$ DNA between the two germplasm types. The six tested almond trees averaged $6.26 \times 10^{-2}$ ng $X f$ DNA/ng total DNA, whereas $7.20 \times$ $10^{-5} \mathrm{ng} X f \mathrm{DNA} / \mathrm{ng}$ total DNA was quantitated in the sampled peach tree. Leaf petioles harvested from water-inoculated peach and almond controls as well as all PEAL trees were absent of $X f$ DNA as determined by quantitative real-time PCR.

These additional samples also allowed analysis of variability in $X f$ titer near the inoculation site in the six $X f$-infected almond trees. At 21 weeks postinoculation, $X f$ titer at the inoculation site differed significantly $(\mathrm{F}$ ratio $=4.07, \mathrm{df}=5,17, P=0.021)$ among almond trees. Titer of tree five averaged $1.24 \times$ $10^{-1} \mathrm{ng} X f \mathrm{DNA} / \mathrm{ng}$ total DNA, which differed significantly $(P<0.05)$ from trees two and six, averaging $3.21 \times 10^{-2}$ and $4.76 \times 10^{-2} \mathrm{ng} X f$ DNA/ng total DNA, respectively (Table 1 ). Although differences in $X f$ titers of these trees were statistically significant, ALSD differences incurred by almond trees infected with such variable levels of $X f$ may not be. The six inoculated almond trees infected with these variable levels of $X f$ expressed only minor differences in tree vigor and ALSD symptoms during the course of the study.

At 24 weeks postinoculation, multiple petiole samples along the meristematic axis were harvested from three $X f$-infected almond trees to examine whether differences existed in $X f$ titer between trees and between vertical sections within trees. $X f$ titer was influenced significantly by almond tree $(\mathrm{F}$ ratio $=3.71$, $\mathrm{df}=2,35, P=0.036)$, but no significant differences in $X f$ titer were noted between tree vertical sections within sampled trees $(\mathrm{F}$ ratio $=2.01, \mathrm{df}=3,35, P=0.134)$. Averaged across tree vertical sections, $X f$ titer throughout the scion of almond tree five was significantly $(P<0.05)$ higher than that of trees one and four (Fig. 2A), reinforcing our previous observations of significant $X f$ titer differences near the inoculation site. Comparing tree vertical sections across the three almond trees, $X f$ titer was numerically 


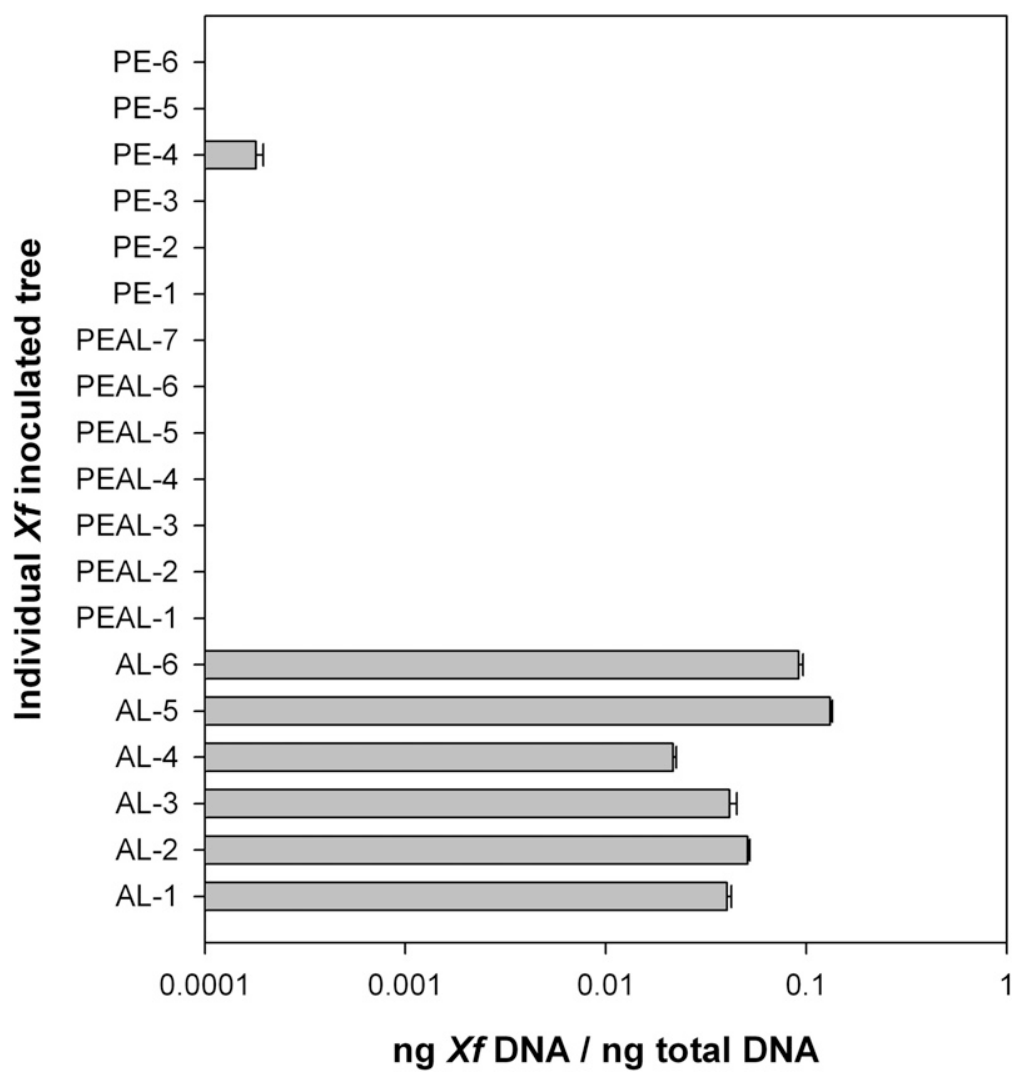

Fig. 1. Initial Xylella fastidiosa titer in petioles harvested near the inoculation site of mechanically inoculated peach (PE), peach-almond hybrid (PEAL), and almond (AL) trees 20 weeks postinoculation as determined by quantitative real-time polymerase chain reaction. Bars represent SES.

Table 1. Titer of Xylella fastidiosa in needle inoculated almond trees 21 weeks postinoculation as determined by quantitative real-time polymerase chain reaction.

\begin{tabular}{lc}
\hline Almond tree & Titer $(\mathrm{ng} X f \mathrm{DNA} / \mathrm{ng} \text { total DNA })^{\mathrm{z}}$ \\
\hline 1 & $6.64 \times 10^{-2} \mathrm{ab}^{\mathrm{y}}$ \\
2 & $3.21 \times 10^{-2} \mathrm{~b}$ \\
3 & $5.32 \times 10^{-2} \mathrm{ab}$ \\
4 & $5.27 \times 10^{-2} \mathrm{ab}$ \\
5 & $1.24 \times 10^{-1} \mathrm{a}$ \\
6 & $4.76 \times 10^{-2} \mathrm{~b}$ \\
\hline $\mathrm{z} X f$ titer based on three independent DNA
\end{tabular}

${ }^{\mathrm{z}} X f$ titer based on three independent DNA extractions from petiole samples collected near the inoculation site.

${ }^{y}$ Values followed by the same letter within a column are not significantly $(P<0.05)$ different according to Tukey's honestly significant difference test.

lowest $\left(1.25 \times 10^{-2} \mathrm{ng} X f\right.$ DNA $)$ in the third section above the inoculation site and highest $\left(1.78 \times 10^{-2}\right.$ ng $X f$ DNA $)$ in the meristematic section (Fig. 2B), although the differences between vertical sections was nonsignificant.

\section{Discussion}

We examined potential host suitability of prospective almond rootstock germplasm in this study using a virulent $X f$ isolate obtained from an ALSD-affected tree in the San Joaquin Valley. Although numerous ALSD-causing $X f$ isolates exist, M23 was chosen as a representative as a result of its discovery in the region where commercial tree nurseries provide planting stock to almond growers and its apparently greater virulence at lower titers in in good agreement with previous reports (Almeida and Purcell, 2003a, 2003b).

The absence of detectable $X f$ DNA in inoculated PEAL trees is an important observation for commercial almond tree nurseries. PEAL hybrids have become increasingly popular rootstock choices for California almond growers to enhance root anchorage and increase scion vigor. Increased demand for PEAL rootstocks by almond growers translates to a higher percentage of commercial nursery acreage being planted with these interspecific hybrids. If PEAL hybrids were susceptible to the $X f$ isolates endemic to regions where commercial almond nursery stock was grown, insect vectors would have a larger window of opportunity to infect planting stock and thereby disseminate $X f$-infected trees to new orchard plantings. Because no $X f$-resistant almond cultivars have yet been detected and Citrus-interspecific hybrids created from $X f$ susceptible $\times X f$-resistant parents have all shown to carry detectable levels of $X f$ (Coletta-Filho et al., 2007), the $X f$ host suitability status of PEAL hybrids was in question. The $X f$ susceptibility of almond accession Y113-20-99 is without question as is the $X f$ resistance demonstrated by $\mathrm{P} 248-139$ peach trees. Although no broad generalizations can be stated relative to $X f$ host suitability of all PEAL hybrids from the current study's results, the data are encouraging and suggest that these interspecific hybrids are not a primary inoculum source of ALSD in orchards where PEAL hybrids have been used as rootstocks.

With the overwhelming majority of rootstock grown for commercial almond plantings being either seedling peach or clonal PEAL hybrids, our results suggest that rootstocks from California's commercial tree nurseries are not primary inoculum sources for ALSD trees found in commercial almond plantings. Almond seedlings are used as rootstocks for almonds in other growing regions (Psallidas, 1989), but they are not offered to commercial growers as rootstock choices for almond in California. Transmission of $X f$ from infected rootstocks to scions propagated to them has been demonstrated previously in Prunus (Latham et al., 1980), and this would be a concern in California almond tree nurseries if almond seedlings were used as common rootstocks. June-budding of almonds to vigorously growing rootstocks generally begins by the middle of May in San Joaquin Valley nurseries with almond bud push beginning 20 to $30 \mathrm{~d}$ after propagation. Hence, although the common rootstocks used for almond may not be suitable hosts for $X f$, almond scions propagated to them would generally be growing and available for $X f$ transmission from infected insect vectors during the final days of June. Although successful transmission of $X f$ from infected vectors to the succulent scions may not be statistically common, it may account for the low levels of ALSD-affected trees observed in commercial almond plantings without other obvious sources of primary inoculum adjacent to them.

Backcrossing of PEAL hybrid 062002 to both Y113-20-99 almond and P248-139 


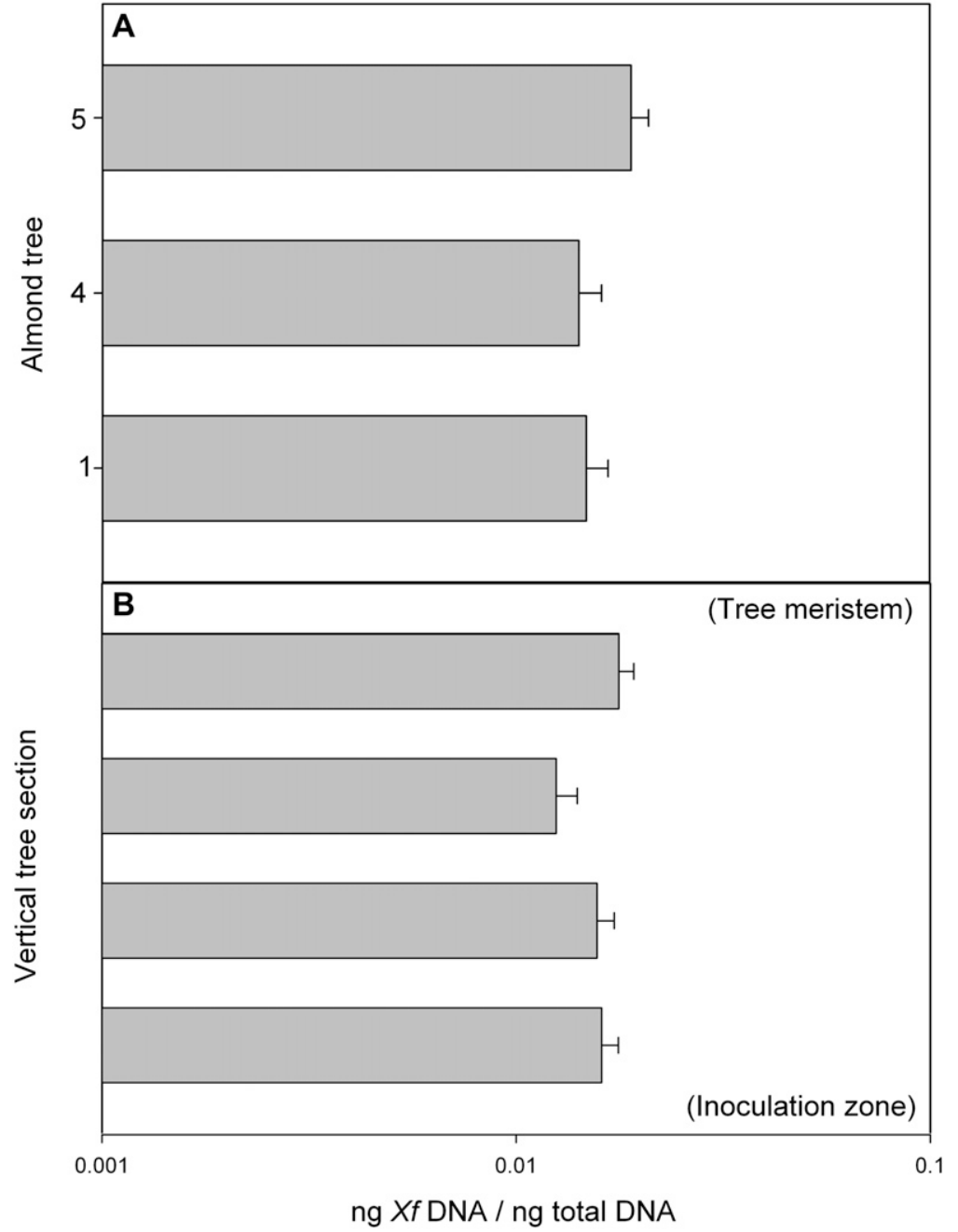

Fig. 2. (A) Xylella fastidiosa $(X f)$ titer variability between trees. Multiple pairs of petioles were harvested sequentially in each of four vertical sections along the main growing axis from three trees of almond selection Y113-20-99. Titers from each tree were averaged; bars represent SES. (B) $X f$ titer variability between vertical growth sections. Petioles were harvested from three trees of almond Y113-20-99 in each of four vertical sections along the main growing axis. Titers from each section were averaged; bars represent sEs.

peach will provide further opportunities to understand host suitability of Prunus germplasm to California $X f$ isolates. Advanced generation PEAL hybrids are currently being evaluated as potential seedling rootstocks for almond (Ledbetter and Sisterson, 2008), so understanding the degree of $X f$ susceptibility in complex hybrids of subgenus Amygdalus is already an important part of almond rootstock evaluation.

\section{Literature Cited}

Almeida, R.P.P. and A.H. Purcell. 2003a. Biological traits of Xylella fastidiosa strains from grapes and almonds. Appl. Environ. Microbiol. 69:7447-7452.

Almeida, R.P.P. and A.H. Purcell. 2003b. Homalodisca coagulata (Hemiptera, Cicadellidae) Transmission of Xylella fastidiosa to almond. Plant Dis. 87:1255-1259.

Anon. 2008. Non-citrus fruits and nuts 2007 summary. U.S. Department of Agriculture, National Agricultural Statistics Service, Fr Nt 1-3 (08) a.

Chen, J., R. Groves, E.L. Civerolo, M. Viveros, M. Freeman, and Y. Zheng. 2005. Two Xylella fastidiosa genotypes associated with almond leaf scorch disease on the same location in California. Phytopathology 95:708-714.

Chen, J.C., S. Livingston, R.L. Groves, and E.L. Civerolo. 2008. High throughput PCR detection of Xylella fastidiosa directly from almond tissues. J. Microbiol. Methods 73:57-61.

Coletta-Filho, H.D., E.O. Pereira, A.A. Souza, M.A. Takita, M. Cristofani-Yale, and M.A. Machado. 2007. Analysis of resistance to Xylella fastidiosa within a hybrid population of Pera sweet orange $\times$ Murcott tangor. Plant Pathol. 56:661-668.

Davis, M.J., W.J. French, and N.W. Schaad. 1981. Axenic culture of the bacteria associated with phony disease of peach and plum leaf scald. Curr. Microbiol. 6:309-314.

de Lima, J.E.O., V.S. Miranda, J.S. Hartung, R.H. Brlansky, A. Coutinho, S.R. Roberto, and E.F. Carlos. 1998. Coffee leaf scorch bacterium: Axenic culture, pathogenicity and comparison with Xylella fastidiosa of Citrus. Plant Dis. 82:94-97.

Dellaporta, S.L., J. Wood, and J.B. Hicks. 1983. A plant DNA minipreparation, version II. Plant Mol. Rptr. 1:19-21.

Francis, M., E.L. Civerolo, and G. Bruening. 2008. Improved bioassay of Xylella fastidiosa strains using Nicotiana tabaccum cultivar SR1. Plant Dis. 92:14-20.

Freitag, J.H. 1951. Host range of Pierce's disease virus of grapes as determined by insect transmission. Phytopathology 41:920-934.

Groves, R.L., J. Chen, E.L. Civerolo, M.W. Freeman, and M.A. Viveros. 2005. Spatial analysis of almond leaf scorch disease in the San Joaquin Valley of California: Factors affecting pathogen distribution and spread. Plant Dis. 89:581589 .

Hernandez-Martinez, R., T.R. Pickard, H.S. Costa, D.A. Cooksey, and F.P. Wong. 2006. Discovery and characterization of Xylella fastidiosa strains in southern California causing mulberry leaf scorch. Plant Dis. 90:1143-1149.

Hopkins, D.L. and A.H. Purcell. 2002. Xylella fastidiosa: Cause of Pierce's disease of grapevine and other emergent diseases. Plant Dis. 86:1056-1066.

Latham, A.J., J.D. Norton, and M.W. Folsom. 1980. Leaf scald on plum shoots growing from disease-free buds. Plant Dis. 64:995-996.

Ledbetter, C.A., J.C. Chen, S. Livingston, and R.L. Groves. 2009. Winter curing of Prunus dulcis $\mathrm{cv}$ 'Butte,' $P$. webbii and their interspecific hybrid in response to Xylella fastidiosa infections. Euphytica 169:113-122.

Ledbetter, C.A. and M.S. Sisterson. 2008. Advanced generation peach-almond hybrids as seedling rootstocks for almond: First year growth and potential pollenizers for hybrid seed production. Euphytica 160:259-266.

Li, W.B., W.D. Pria, D.C. Teixeira, V.S. Miranda, A.J. Ayers, C.F. Franco, M.G. Costa, C.X. He, P.I. Costa, and J.S. Hartung. 2001. Coffee leaf scorch caused by a strain of Xylella fastidiosa from citrus. Plant Dis. 85:501-505.

Mircetich, S.M., S.K. Lowe, W.J. Moller, and G. Nyland. 1976. Etiology of almond leaf scorch disease and transmission of the causal agent Phytopathology 66:17-24.

Montero-Astúa, M., J.S. Hartung, E. Aguilar, C. Chacón, W. Li, F.J. Albertazzi, and C. Rivera. 2007. Genetic diversity of Xylella fastidiosa strains from Costa Rica, Sao Paulo, Brazil and the United States. Phytopathology 97:13381347.

Psallidas, P.G. 1989. Bacterial diseases of almond rootstocks. Options Méditerranéennes-Série Séminaires 5:25-31.

Raju, B.C., J.M. Wells, G. Nyland, R.H. Brlansky, and S.K. Lowe. 1982. Plum leaf scald: Isolation, culture and pathogenicity of the causal agent. Phytopathology 72:1460-1466.

Redak, R.A., A.H. Purcell, J.R.S. Lopes, M.J. Blua, R.F. Mizell, and P.C. Andersen. 2004. The biology of xylem fluid-Feeding insect vectors of Xylella fastidiosa and their relation to disease epidemiology. Annu. Rev. Entomol. 49:243-270.

Rehder, A. 1940. Manual of cultivated trees and shrubs hardy in North America, exclusive of the subtropical and warmer temperate regions. Second Revised and Enlarged Ed. Macmillan, New York, NY

Roberto, S.R., P.R.S. Farias, and A. Bergamin Filho. 2002. Geostatistical analysis of spatial dynamics of Citrus variegated chlorosis. Fitopatol. Bras. 27:599-604.

Wells, J.M., B.C. Raju, and G. Nyland. 1983 Isolation, culture and pathogenicity of the bacterium causing phony disease of peach Phytopathology 73:859-862.

Wells, J.M., B.C. Raju, J.M. Thompson, and S.K. Lowe. 1981. Evidence of the common etiology of phony peach and plum leaf scald diseases. Phytopathology 71:1156-1161. 